\title{
Experiential Learning in a Common Core Curriculum: Student Expectations, Evaluations, and the Way Forward
}

\author{
Gavin W. Porter (Corresponding author) \\ Faculty of Science, University of Hong Kong \\ 316 Run Run Shaw Building, Pokfulam, Hong Kong, China \\ Tel: 852-2241-5195 E-mail: porterg@hku.hk \\ Jessica A. King \\ Department of Earth Sciences, Faculty of Science, University of Hong Kong \\ 403a James Lee Building Pokfulam, Hong Kong, China \\ Tel: 852-2241-5473Ｅ-mail: jessking@hku.hk \\ Nathalie F. Goodkin \\ Department of Earth Sciences, Faculty of Science, University of Hong Kong \\ 318b James Lee Building Pokfulam, Hong Kong, China \\ Tel: 852-2219-4816Ｅ-mail: goodkin@hku.hk \\ Cecilia K. Y. Chan \\ Centre for the Enhancement of Teaching and Learning, University of Hong Kong \\ 305 Run Run Shaw Building, Pokfulam, Hong Kong, China \\ Tel: 852-2857-8534Ｅ-mail: ckchan09@hku.hk
}

Received: January 11, 2012 Accepted: January 13, 2012 Online Published: April 17, 2012

doi:10.5539/ies.v5n3p24

URL: http://dx.doi.org/10.5539/ies.v5n3p24

\begin{abstract}
Universities are becoming increasingly conscious of how learning activities align with the attributes they desire in their graduates. Experiential learning is viewed by many institutions as an essential activity for students to gain attributes such as problem solving skills, observation skills, advocacy, and critical thinking. An experiential learning activity, in the form of an environmental fieldtrip, was examined in the context of a university's new common core curriculum. Student expectations were compared to evaluation of the fieldtrip itself, and guidelines for future trip outings are made in consideration of both published works and our own experiences. The ability of departments and faculties to engage students in beneficial and enjoyable learning will be of utmost importance in attracting student enrollment. This is particularly pressing in universities that are transitioning into less differentiated first year intakes.
\end{abstract}

Keywords: Curriculum, Reform, Evaluation, Field trip, Environmental, Expectations

\subsection{Introduction}

\subsection{Universities in Transition}

Many universities herald their experiential learning opportunities on offer to students. These can function not only as great educational opportunities, but also bring positive publicity for the university (i.e. poverty outreach, high-profile industry collaborations, disaster relief/rebuilding), serving as an attractive marketing device to attract prospective students and donors. As universities continue to develop and enhance their experiential learning programs, several questions should be considered: How do instructors devise effective experiential learning activities? What do students expect to learn from these and are these expectations being met? Should blueprints be provided for new staff to plan and implement effective experiential learning? To what extent are instructors drawing 
from the existing literature on experiential learning when they are planning their own field trips? Do instructors have the time/means to do so? Experiential learning will form a key pillar of exciting new curriculum reforms taking place at the University of Hong Kong (HKU); answers to these questions will be of prime importance as the university moves forward.

\subsection{Implementation of a New Curriculum}

HKU's new common core curriculum will accompany the addition of a full year of university studies and has gained recognition on a global scale (Gooch, 2011). The University has thought carefully about its mission, and has chosen to focus this new curriculum on the commonality of human experiences. The curriculum seeks to identify issues of deeply profound significance to humankind, the core intellectual skills that all HKU undergraduates should acquire, and the core values they should uphold. In their first year at HKU, students will engage in issues-based courses, organized around 4 main areas of inquiry: Scientific and Technological Literacy, Humanities, Global Issues, and China: Culture, state, and society. The goal is to enable students to develop capabilities in six key areas:

i) Pursuit of academic/professional excellence, critical intellectual enquiry and life-long learning

ii) Tackling novel situations and ill-defined problems

iii) Critical self-reflection, greater understanding of others, and upholding personal and professional ethics

iv) Intercultural understanding and global citizenship

v) Communication and collaboration

vi) Leadership and advocacy for the improvement of the human condition (http://tl.hku.hk/reform)

Similar lists of desired attributes in graduates have been published by other universities (Quinn, 2009). There is also desire from the private sector and industry for knowledge workers with problem solving ability, creativity, and talent; so called "gold-collar workers" (Wonacott, 2002). Accordingly, many universities are steering away from traditional didactic models (lectures with one-way transfer of information from teacher to student) and towards active learning that should better equip graduates with the desired attributes. There is certainly room and high value for disciplinary knowledge, but one hopes that students approach it from a mindset that allows them to apply this knowledge. This is particularly important for students who are used to valuing memorization and recitation of facts for good grades. The common core curriculum is attempting to encompass diverse forms of learning activities and assessments. All faculties at HKU have incorporated experiential learning into their curricula and some have already made it a graduation requirement. It is hoped that students entering a first year common curriculum will then adapt to experiential learning as a norm (Quinn, 2009), with positive benefits for their future studies.

\subsection{Outcomes-Based Approaches to Student Learning}

In an outcomes-based approach to student learning (also known as OBASL, OBL, or OBTL), the instructor must ask themselves what they want the student to learn (outcomes), how the student will learn (learning activities), and how the student's learning will be measured (assessments) (Biggs, 1996; Biggs \& Tang, 2006; Salter, Pang, \& Sharma, 2009). In a forward-thinking educational environment, all of these components are aligned with each other, and furthermore, they are aligned with the desired attributes of the university's graduates. Instructional alignment studies have indicated large gains in student performance in aligned versus misaligned situations (Biggs, 1996; Cohen, 1987). This is an aspect amenable to change, shows robust results, and, unfortunately, is often ignored (Cohen, 1987). Experiential learning can be viewed as a key aligning factor for the common core curriculum.

\subsection{Experiential Learning}

In looking for theoretical underpinnings for experiential learning, the work of Kolb is often cited. Kolb melded the models of Lewin (cyclical feedback processes), Dewey (cyclical - with integration of judgment, impulse, observation, knowledge, and purpose) and Piaget (assimilation of events and experiences from the world into existing concepts and schemas) in order to formulate a theory of experiential learning with the student's subjective experience at the forefront (Kolb, 1984). Experiential learning cycles typically involve four steps: i) concrete experience, ii) observation and reflection, iii) abstract conceptualization (concluding/learning from the experience), and iv) active experimentation (trying out what you have learned) (Petkus, 2000). The work of David Thornton Moore nicely translates some of the theory into current practical experiences in which University students are engaging. One of the important issues identified is how to make students engage with experiential learning in a deeper manner and what the university's and instructor's role should be in trying to make this happen (Moore, 2010). If students are not achieving deeper outcomes from experiential learning, then the instructors may need to re-think and re-design their activities to further stress critical thinking (Moore, 2010). Some literature suggests that experiential learning should not be conceived in terms of outcomes, but as a process (Kolb, 1984). We view the 
building of the process skills, the obtaining of local and historical knowledge, and emotional impacts to increase advocacy in the future, as positive outcomes of a fieldtrip.

In addition to environmental fieldtrips, programs such as community service learning, cooperative education placements in the workforce, clinical practicum, and exchanges can also form effective experiential learning activities. The discipline often dictates what the experience will be (i.e. co-op placements are common for engineering students, clinical practicum are a necessity for nursing students). In the common core curriculum, HKU is offering experiential learning to students of different disciplines, working together at the same time, as the enrolment for these classes melds students from physical science, education, actuarial science, architecture, engineering, economics, linguistics, journalism, medicine, law and finance.

Ideal fieldtrips contain several key processes or steps. Reasonable intellectual demands should be required of the students (Openshaw \& Whittle, 1993), and the levels of novelty and preparation should be carefully balanced (Cotton \& Cotton, 2009). There should be communication of instructional goals (Griffin \& Symington, 1997), and preparation, both for students and instructors, should occur prior to the trip (Openshaw \& Whittle, 1993). An investigatory approach is preferable to a confirmatory approach (Openshaw \& Whittle, 1993; Nir Orion \& Hofstein, 1997), and ideally, student environmental advocacy/compassion also arises from the experience (Stapp, 2000). Finally, the faculty need to plan to monitor the effectives of their student's experiences and think of how to build upon these outcomes (Amos, 2006).

The key issues this manuscript addresses are: What can be gained from eliciting student's expectations for an experiential learning outing, and how can we reconcile these with evaluations that occur after the fieldtrip? What does each of these tell us? How will they inform the planning of future experiential learning activities? How should instructors use feedback to improve future experiential learning activities? Many instructors at HKU are leading experiential learning activities for the first time. Furthermore, the freshman students are having their first experiential learning trips at the university level. At an institution-wide level, $\mathrm{HKU}$ is anxious to learn from these initial experiences in pilot courses in order to improve for the full implementation of the common core curriculum in 2012. This study will serve not only as a reference standard for common core courses within HKU, but should also be of substantial interest to the larger teaching, experiential learning, and environmental education groups.

\section{Methodology}

\subsection{The Course Context}

Looking at the larger context of the course "Understanding Climate Change", students were provided with the scientific literacy needed to understand climate change and consider existing and proposed solutions at multiple levels (individual, local, and global). Examination of media relating to climate change was another sizeable aspect of the course (i.e. films, newspaper articles, radio broadcasts). The instructors wanted the students to be able to see multiple sides of an argument, in favor of, or against the notion of man-made global warming. Students were also exposed to real-world data sets, in the form of ice core data analysis exercises, where calculations were made using multiple parameters to investigate global climate change over long periods of time.

Some of the material discussed during the fieldtrip was covered beforehand in lectures (carbon sinks and reservoirs, historical eras, periods, and epochs). Identical fieldtrips were given twice; once after the sixth, and once after the seventh lecture in the course (March 19 and 26, 2011). Approximately half of the class attended each field trip. Enrolment was 100 students which is currently the maximum intake for a common core course.

\subsection{The Lai Chi Chong Fieldtrip}

Lai Chi Chong is located on the eastern side of Tolo Channel in the Northeastern New Territories area of Hong Kong. It has been designated as a Site of Special Scientific Interest (SSSI) by the Agriculture, Fisheries and Conservation Department because of its geological significance. Rock formations and other key environmental features of Lai Chi Chong were investigated between the Tai Pak Kok and Pak Kok Chai regions. Travel time to the site was approximately 45 minutes by ferry, from our meeting point in the Kowloon area of Hong Kong.

The students of the Understanding Climate Change course were taken on this trip to examine how the geological record can be used to re-construct past environments. The rocks at Lai Chi Chong provide evidence as to what the environment was like at the time they were formed. The students were led through a series of questions which would illuminate what Hong Kong climate was like in the Late Jurassic to Early Cretaceous periods of the Mesozoic era. ( 140 million years ago). Students were guided around 8 stops in the Lai Chi Chong area by a lead instructor for the course. These stops emphasized geological features such as lapilli tuffs, tuffaceous sedimentary rocks/tuffite, slump structures, and black shale. Tangible evidence of historical changes in landforms (i.e. volcanic activity), was examined by the students and then related back to mechanisms impacting climate. The investigation of the site 
lasted approximately 4 hours, not including travel time to and from the site.

\subsection{Fieldtrip Worksheet}

Students were asked to complete a worksheet during the fieldtrip, and had additional time to complete the worksheet on the return ferry ride. Questions on the worksheet were as follows:

1) How would you describe the present climate of Hong Kong?

2) The first rock you come to at site 3 is a light colored rock called a lapilli tuff that is approximately 130-145 million years old. It is composed of volcanic ash and pebbles. How was it formed? What does that tell you about the environment of Hong Kong 140 million years ago?

3) The place you come to at site 6 is a folded sedimentary rock. How was it formed? What does this tell you about the environment in Hong Kong 140 million years ago?

4) What causes slump folding?

5) What role do volcanoes play in influencing global climate?

6) How would major episodes of volcanism like those shown at Lai Chi Chong effect global climate change?

7) How can looking at the geological record of environmental and climatic change be useful in the study of future climate change?

8) What are the problems with using geological information to help in predicting future climate change?

\subsection{Expectations Questionnaire}

A total of 93 students in the class participated in the fieldtrip. An open-ended questionnaire was given to the students prior to the fieldtrip. In this questionnaire, they were asked: What are your expectations for the fieldtrip to Lai Chi Chong on Saturday? What do you expect to learn? How do you expect to benefit from the time there? A total of 66 students (71\% of the students) in the class completed the expectations questionnaire. The students spent 5-10 minutes filling out their responses to these questions, either in a tutorial session, or just prior to embarking on the ferry to Lai Chi Chong.

\subsection{Experiences and Evaluation of Trip}

Questionnaires including both open-ended, and quantitative sections were given to the students immediately after completion of the fieldtrip. These questionnaires were completed by 47 students in the first fieldtrip outing and 46 students in the second outing (100\% of the students). To evaluate their experiences in the field, students were asked to complete the following surveys:

1) This fieldtrip had a significant impact on my learning for the course

2) As a result of the fieldtrip, I understand the subject matter better than before

3) I learned some skills and knowledge of the subject that I could not have learned in a classroom context

4) I have changed to a more positive attitude towards fieldtrips as learning activities

5) I am more comfortable with teachers/students in the fieldtrip time than in the classroom

6) Overall, I think the fieldtrip has enhanced my learning and interest for the course

7) The field trip has achieved the learning outcomes of the course

8) I know the assessment and grading criteria of the fieldtrip

9) Can you suggest ways we can improve the fieldtrip for next year?

10) What is the one thing you will remember about this trip after you finish this course?

Items 1 to 6 were answered on a 5 point Likert scale: Strongly agree (1), Agree (2), Neutral (3), Disagree (4), Strongly disagree (5). Items 7 and 8 were answered with a yes or no, while questions 9 and 10 were open-ended. Numeric responses were entered into either Graphpad Prism or Excel to produce appropriate charts and tables. Responses to open-ended questions were examined and then categorized into common themes.

\section{Results}

\subsection{Student Expectations for Field Trip}

Analysis of the expectations comments proved to be quite valuable, and six themes emerged in regards to student expectations (Table 1). The students wanted: 
1) To learn how climate affects the environment by seeing a tangible change or historical progression in the landforms

2) To gain local knowledge of how global climate change pertains specifically to Hong Kong

3) To gain practical knowledge, such as how to analyze rock formations, and perform some simple experiments and data collection

4) Application of lecture knowledge to the field environment/relate information gained on fieldtrip back to lectures

5) Some emotional impact through closer contact with nature

6) Leisure

This desire for active experimentation is indeed something that should be explored and nurtured in future experiential learning outings, particularly those that are occurring in Common Core courses in the Scientific and Technological Inquiry area of investigation (Openshaw \& Whittle, 1993; Nir Orion \& Hofstein, 1997). The student's expectation comments mirror sound guidelines for an experiential learning activity. Surprisingly, the main objectives of the fieldtrip were nicely distilled by the students without any prompting from instructors, as the questionnaire was completely open-ended. If the comments accurately reflect the student's attitudes, it seems as though most students in their first year at HKU are already in a good frame of mind to approach an experiential learning fieldtrip.

Specific quotations for expectations included the following:

- "See special rocks, landscape, and learn its origin - how they are related to climate change, and some useful geographic knowledge

- "Find evidence indicating recent global warming"

- "Learn how climate influences the environment in a long term perspective"

- "Know more about the factors that may result in climate change, and know how climate change effects the environment”

- "Learn how global warming has changed our environment and how we can protect it effectively"

- "Understand climate change as it pertains to Hong Kong"

- "Learn something I cannot get from a lesson like how to investigate the rocks or trees and explore their linkage to climate change - can they show some evidence the climate in Hong Kong is changing or not?"

\subsection{Student Expectations for Field Trip}

In examining the responses, the majority of students had a favorable view of the fieldtrip (Figure 1). Student quotations for "ways to improve trip" included:

- "Smaller subgroups"

- "Tutor should bring a microphone"

- "Better information on the itinerary of the day, with more reference points so that we know what we are going to look at and in what order"

- "Look at a greater variety of landscapes"

- "More emphasis on site and how it relates to climate change"

- "More background information"

- "Carry out some experiments"

Student quotations for "one thing I will remember" included:

- "Beautiful rocks with an explanation behind them"

- "Learning from activities is better than learning from textbooks"

- "Global climate change can be investigated by various sources"

- "I will remember why some sedimentary rocks are black in color but some are not which is due to the presence or absence of oxygen"

- "Hong Kong was once an active volcanic area"

- "Different types of rocks and how they can be affected by earthquakes and volcanic eruptions"

- "How to observe different characteristics of rocks (grain size, layering, structures, etc.)" 
A majority of the students thought that the fieldtrip had achieved the learning outcomes of the course. A lower percentage of students stated that they knew the assessments and grading criteria of the fieldtrip (Figure 2). The students provided valuable information on how to improve the trip in the future. Most evaluation comments dealt with logistical issues. We are taking this as a positive sign, as these tend to be the easiest issues to fix. Some complaints were directly related to one another (i.e. have smaller subgroups/have tutor use a microphone; changing one of these factors would eliminate the root of both the complaints [unable to hear at times]). One of the teaching assistants echoed the student feedback in terms of the itinerary, as at times, it was difficult to relate what we were looking at with a corresponding question in the worksheet.

Judging from the comments on what they will remember, the students gained some appreciation for hands on learning ("Learning from activities is better than learning from a textbook"), different ways to uncover evidence for global warming ("Global climate can be investigated by various sources"), and specifics on geological investigation ("How to observe different characteristics of rocks [grain size, layering, structures, etc.]").

\subsection{Overall Percentages and Comparison of Expectations and Evaluation Comments}

All expectation and evaluation comments were categorized and the overall percentage of the types of comments made was also calculated (Figure 3). For example, about a third of all the expectations comments (31\%) indicated a desire for a leisure element on the fieldtrip (Figure 3a). This should not be interpreted as a third of the students only being concerned with leisure, as these comments were often accompanied by a more intellectually substantial comment from the same student. An explicit desire for leisure on an environmentally-oriented fieldtrip is not unusual (N. Orion \& Hofstein, 1991). The second most frequent expectation was for tangible evidence to be seen for climate change or historical climate patterns from the fieldtrip (27\%). The students also desired to gain local and practical knowledge (14\% and $18 \%$ of comments), and be able to apply lecture material during the trip (9\%). For the "ways to improve the fieldtrip" (Figure 3b), logistical comments dominated the list (52\%). Some logistical aspects were not under our control, such as the weather conditions. Other comments could be categorized into content, explanations and delivery, report/handout, and preparation, which all formed much lower percentages of the comments. Students, as well as the teaching assistant, gained a new appreciation for the natural beauty inherent in a geological field study, and many students indicated the "one thing they will remember" will be specifics of rock composition/formation. For the "one thing you will remember" question (Figure 3c), a majority of the comments (64\%) indicated something pertaining to rocks/geology. The second most remembered item referred to logistics or travel (27\%); ideally this will not be as much of an issue in subsequent trips.

\section{Discussion}

\subsection{Experiential Learning as an Engaging Factor for Students}

Enrolment in undergraduate science programs has been a major concern in the past for many universities (Turner \& Bowen, 1990). In the last four years, HKU has transitioned to a system where each student will enter the university in an undifferentiated state (no major declared), but allocated to a specific faculty (i.e. Science, Law, Social Science etc.). If science is taught in a dry manner with no experiential aspects built in, or if departments have no or particularly weak common core course offerings, the risk of losing first year students to departments with more compelling courses looms large. This will be a concern for first year course offerings from all departments in all faculties. Several departments within the Faculty of Science are hoping that these types of experiential learning endeavors, where students can have hands on experiences, will positively contribute to their interest in science in the future, and also equip graduates with highly desirable attributes. Some American universities have initiated significant overhauls to increase the experiential and experimentally-driven aspects of their first year curriculum, with impressive results (Mervis, 2010).

\subsection{What Can be Gained from Eliciting Expectation and Evaluation Data? What Does Each of These Tell Us?}

Comments in the expectations surveys were more substantive than comments in the open sections of the fieldtrip evaluation forms. Students spent approximately the same amount of time on each (a few minutes). Ironically, the expectations forms provided better feedback than the evaluation forms for the planning of future trips, at least in terms of broader missions, and the types of investigations that the students would like to embark on (i.e. active experimentation, linkage between climate history and observations with direct observations). More specific logistical details were, of course, better addressed in the evaluations. With the expectations comments, the focus was more idealistic. The idealistic expectations segment puts more focus on content and goals for the trip, while the evaluative segment puts the emphasis on how best to experience the content and goals. Combining these two segments made for tremendously helpful feedback for the instructors. Eliciting student expectations for fieldtrips is thus highly recommended for staff planning fieldtrips for the first time. 
We attempted to draw some parallels between expectation and evaluative comments (Table 4). Expectations for leisure were satisfied through "rock climbing" and experiencing the "sea and fresh air". Students expected to gain local knowledge; in evaluations they indicated that they would remember that "Hong Kong was once an area of seismic activity" and "Hong Kong was once a volcanic area". Practical knowledge was gained through students learning "how to observe different characteristics of rocks" and by "touching/categorizing rocks with multiple senses". The comment that "learning through activities is better than learning through a textbook", nicely sums up the instructor's desire to put forth the extra effort for such a trip, the faculty's desire to engage first year students, and the university's desire to change the culture of learning for the new curriculum.

One of the striking pieces of feedback on the end-of-year evaluations of the course (a compulsory university instrument) was the number of student comments in favor of the fieldtrip. We were glad to see the positive student feedback - even more exciting is the feeling that we can still make dramatic improvements in the future. We would like to increase even more, our attempts to turn the students into more active scientists - can they actually collect meaningful data, and write up a report that will be of interest not only to them, but to a larger scientific community, or even better, their home city of Hong Kong?

\subsection{The Way Forward: How Should Instructors Use Feedback to Plan for Future Experiential Learning Activities?}

Taking into account one of the guidelines for ideal fieldtrips (Amos, 2006), we are thinking of how to build on the effectiveness of the fieldtrip and share our wisdom with HKU and other interested parties in the ecological and experiential learning fields. We have compared the completed (2011) with the ideal planned (2012) version of the experiential learning trip, and broken this down into 4 segments: pre-trip planning, trip, post-trip, and relevance of trip (Table 5).

For pre-trip planning, in 2011, the learning objectives were firmly in place for the course, and some of the content for the fieldtrip was covered during lecture periods (see also methodology section). We are leaning towards something more self-directed on the part of the students for the 2012 and future trips, whereby we would divide the class into subgroups with the idea to tackle an environmental issue specific to Hong Kong, on multiple fronts. For example, one of many possible ideas includes getting students to examine temperature differences between Hong Kong's various environments (urban "heat islands", cooler rural areas), and identify resulting impacts on the population.

There is no exact time period or cut-off time to determine "when the learning occurred" for the current trip. Taking into account experiential learning cycles, one expects that fieldtrip experiences will pay dividends long into the future. In 2011, we had what could be called a synchronous format, with the students going through the fieldtrip at the same time. In the future we are considering a more asynchronous trip format, with students playing multiple roles (data collection, interpretation of results, dissemination of results to public, and public outreach through web and other outlets). This expands the duration of the fieldtrip, in so far as the students will have to consider the issues on multiple occasions, and may also lead to much different experiences, based on the subgroups of students. This could have positive and negative aspects. On the positive side, students can align themselves better with their interests - data collection for those interested in pursuing environmental science in the future, web design for those interested in computers, community outreach for other interested students. On the negative side, the students that choose to develop the web design or community outreach may not have the same hands-on environmental experience. They help the data come to life, but don't get the same firsthand experience of field work and collecting the data. To address this, we plan to have subgroups meet with each other and discuss their experiences together. One experience should be no less valid overall than another; implementation and effective communication of data is as important to science as its collection. One must shift the outlook of the course to experiencing "an issue" rather than an "environmental site" per se. This issues based approach would align itself well with the mission of the common core curriculum.

The formal post-trip phase in 2011 was brief, with the students finishing questionnaires on environmental observations and analysis of the site, and also their personal evaluations of the trip itself. We would of course include evaluations of future trips, but the post-trip phase in 2012 and beyond would be quite different. We plan to have the groups critique each other's methods and design. Perhaps data collectors think that their results could be disseminated in a more impactful way by the other subgroup of students involved in web design. Perhaps the web designers have questions that need to be answered by the data collectors in order to explain the results logically. These sorts of activities will also be more in line with the common core mission point of "communication and collaboration", and lead to some meta-cognitive reflection on the scientific process itself.

In 2011, all students had some hands-on experience in the field, for many, their first experience - to link climate change through history to environmental and geological signs. Planning for the year ahead, we will aim to 
specifically address an issue of environmental importance to the city of Hong Kong. We hope to generate data of interest to the public and government, and in doing so, increase student engagement even further. The ultimate goal would be to have data with enough significance to warrant its publication in a peer-reviewed scientific journal. Thus, we desire to head in a direction that is more experimental, as opposed to demonstrative, and stir up the student's spirits even more, through a positive impact in their local community. These are lofty goals, but fitting with the common core aims of leadership and advocacy for the improvement of the human condition.

There appears to be a dearth of any specific training in field teaching for academics (Scott, 2011). HKU is attempting to address this at an institutional level by organizing several round-table sharing sessions for those who have organized experiential learning activities. These are undoubtedly beneficial as a showcase for best practices and things that staff would like to see improved upon. This study should serve as a reference for expectations, evaluations, and future aims of experiential learning in common core courses within HKU, and also be of interest to the larger teaching, experiential learning, and environmental education groups.

\section{References}

Amos, R., Reiss, Michael. (2006). What contribution can residential field courses make to the education of 11-14 year olds? School Science Review, 87(321), 1-8. [Online] Available: http://eprints.ioe.ac.uk/455/1/Reiss2006What37.pdf

Biggs, J. (1996). Enhancing Teaching through Constructive Alignment. Higher Education, 32(3), 347-364. http://dx.doi.org/10.1007/BF00138871

Biggs, J., \& Tang, C. (2006). Outcomes-Based teaching and learning (OBTL): What is it, Why is it, How do we make it work? [Online] Available: http://www.cetl.hku.hk/system/files/OBTL_what_why_how.pdf

Cohen, S. A. (1987). Instructional Alignment: Searching for a Magic Bullet. Educational Researcher, 16(8), 16-20. http://dx.doi.org/10.2307/1175370

Cotton, D. R. E., \& Cotton, P. A. (2009). Field biology experiences of undergraduate students: the impact of novelty space. Journal of Biological Education, 43(4), 6p. http://dx.doi.org/10.1080/00219266.2009.9656178

Gooch, L. (2011, January 31, 2011). Hong Kong's Universities decide bigger is better. New York Times. [Online] Available: http://www.nytimes.com/2011/01/31/world/asia/31iht-educLede31.html?pagewanted=all\#

Griffin, J., \& Symington, D. (1997). Moving from task-oriented to learning-oriented strategies on school excursions to museums. Science Education, http://dx.doi.org/10.1002/(SICI)1098-237X(199711)81:6<763::AID-SCE11>3.0.CO;2-O

Kolb, D. A. (1984). Experiential learning : experience as the source of learning and development. Englewood Cliffs, N.J.: Prentice-Hall. [Online] Available: http://www.learningfromexperience.com/images/uploads/process-of-experiential-learning.pdf

Mervis, J. (2010). Better Intro Courses Seen as Key to Reducing Attrition of STEM Majors. Science, 330(6002), 1p. http://dx.doi.org/10.1126/science.330.6002.306

Moore, D. T. (2010). Forms and Issues in Experiential Learning. New Directions for Teaching and Learning(124), 3-13. http://dx.doi.org/10.1002/tl.415

Openshaw, P. H., \& Whittle, S. J. (1993). Ecological field teaching: how can it be made more effective? Journal of Biological Education, 27(1), 9p. http://dx.doi.org/10.1080/00219266.1993.9655305

Orion, N., \& Hofstein, A. (1991). The Measurement of Students' Attitudes Towards Scientific Field Trips. Science Education, 75(5), 513-523. http://dx.doi.org/10.1002/sce.3730750503

Orion, N., \& Hofstein, A. (1997). Development and validation of an instrument for assessing the learning $\begin{array}{lllll}\text { environment of } & \text { outdoor. } & \text { Science } & \text { Education, } & \text { 11p. }\end{array}$ http://dx.doi.org/10.1002/(SICI)1098-237X(199704)81:2<161::AID-SCE3>3.0.CO;2-D

Petkus, E. (2000). A Theoretical and Practical Framework for Service-Learning in Marketing: Kolb's Experiential Learning Cycle. Journal of Marketing Education, 22(1), 64-70. http://dx.doi.org/10.1177/0273475300221008

Quinn, D., \& Shurville, S. (2009). From little things big things grow: scaling up assessment of experiential learning. Campus-Wide Information Systems, 26(5), 329-344. http://dx.doi.org/10.1108/10650740911004769

Salter, D., Pang, M. Y. C., \& Sharma, P. (2009). Active Tasks to Change the Use of Class Time within an Outcomes Based Approach to Curriculum Design. Journal of University Teaching and Learning Practice, 6(1), 27-38. [Online] Available: http://ro.uow.edu.au/jutlp/vol6/iss1/4/ 
Scott, G., Goulder, R, Wheeler, P, Scott, LJ, Tobin, ML., \& Marsham, S. (2011). The Value of Fieldwork in Life and Environmental Sciences in the Context of Higher Education: A case study in learning about Biodiversity Journal of Science Education and Technology. http://dx.doi.org/10.1007/s10956-010-9276-X

Stapp, W. B. (2000). Watershed Education for Sustainable Development. Journal of Science Education and Technology, 9(3), 183-197. http://dx.doi.org/10.1023/A:1009430215477

Turner, S. E., \& Bowen, W. G. (1990). The flight from the arts and sciences: Trends in degrees conferred. Science, 250(4980), 5p. http://dx.doi.org/10.1126/science.250.4980.517

Wonacott, M. E. (2002). Gold-Collar Workers. ERIC Digest (ERIC Publications ERIC Digests in Full Text No. ED467237). [Online] Available: http://purl.access.gpo.gov/GPO/LPS43148 
Table 1. Categorization of comments for the Expectations questionnaire into 6 themes

\begin{tabular}{|c|c|c|c|c|c|}
\hline $\begin{array}{l}\text { Reference to } \\
\text { climate } \\
\text { change/history } \\
\text { (want tangible } \\
\text { evidence) }\end{array}$ & $\begin{array}{l}\text { Local } \\
\text { knowledge }\end{array}$ & Practical knowledge & Leisure & $\begin{array}{l}\text { Emotional } \\
\text { impact }\end{array}$ & $\begin{array}{l}\text { Reinforce/apply } \\
\text { lecture material, } \\
\text { other didactic }\end{array}$ \\
\hline $\begin{array}{l}\text { Learn how } \\
\text { climate affects } \\
\text { the environment } \\
\text { (see a tangible } \\
\text { change through } \\
\text { evidence or see } \\
\text { a historical } \\
\text { progression) } \\
\text { (35) }\end{array}$ & $\begin{array}{l}\text { Understand } \\
\text { climate } \\
\text { change as it } \\
\text { pertains to } \\
\text { Hong Kong } \\
\text { (7) }\end{array}$ & $\begin{array}{l}\text { Learn how to analyze } \\
\text { rock formations/other } \\
\text { geology information } \\
\text { (10) }\end{array}$ & $\begin{array}{l}\text { General leisure } \\
\text { comments (31) }\end{array}$ & $\begin{array}{l}\text { Self-reflection } \\
\text { on own } \\
\text { lifestyle }\end{array}$ & $\begin{array}{l}\text { Apply what we } \\
\text { have learned in } \\
\text { class (7) }\end{array}$ \\
\hline $\begin{array}{l}\text { Specifics on } \\
\text { rock formation } \\
\text { and its relation } \\
\text { to climate } \\
\text { change (4) }\end{array}$ & $\begin{array}{l}\text { Know more } \\
\text { about } \\
\text { natural } \\
\text { landscape in } \\
\text { Hong Kong } \\
\text { (7) }\end{array}$ & $\begin{array}{l}\text { Learn how to protect } \\
\text { the environment (6) }\end{array}$ & $\begin{array}{l}\text { Visual features } \\
\text { (view) (9) }\end{array}$ & $\begin{array}{l}\text { Raise interest } \\
\text { in the natural } \\
\text { environment }\end{array}$ & $\begin{array}{l}\text { Gain a better } \\
\text { understanding of } \\
\text { what we have } \\
\text { learned in class } \\
\text { (2) }\end{array}$ \\
\hline $\begin{array}{l}\text { Find evidence } \\
\text { for recent } \\
\text { global warming } \\
\text { (2) }\end{array}$ & $\begin{array}{l}\text { Observing } \\
\text { natural } \\
\text { surroundings } \\
\text { outside of an } \\
\text { urban area } \\
\text { (4) }\end{array}$ & $\begin{array}{l}\text { Perform some simple } \\
\text { experiments/data } \\
\text { collection (3) }\end{array}$ & $\begin{array}{l}\text { Hiking/adventure } \\
\text { (9) }\end{array}$ & & $\begin{array}{l}\text { Learn something } \\
\text { that cannot be } \\
\text { learned in a } \\
\text { classroom (2) }\end{array}$ \\
\hline \multirow[t]{7}{*}{$\begin{array}{l}\text { Further } \\
\text { understanding } \\
\text { of climate } \\
\text { systems }\end{array}$} & $\begin{array}{l}\text { View unique } \\
\text { structure of } \\
\text { Lai Chi } \\
\text { Chong/Tolo } \\
\text { Harbour (3) }\end{array}$ & $\begin{array}{l}\text { Observe climate change } \\
\text { based on cues from the } \\
\text { environment (2) }\end{array}$ & & & $\begin{array}{l}\text { A more } \\
\text { interactive } \\
\text { learning } \\
\text { experience (2) }\end{array}$ \\
\hline & $\begin{array}{l}\text { See how } \\
\text { human } \\
\text { activities } \\
\text { affect Lai } \\
\text { Chi } \\
\text { Chong/Tolo } \\
\text { Harbour }\end{array}$ & $\begin{array}{l}\text { Act as an } \\
\text { environmental advocate } \\
\text { in the future (2) }\end{array}$ & & & $\begin{array}{l}\text { Gain general } \\
\text { fieldtrip } \\
\text { experience }\end{array}$ \\
\hline & & $\begin{array}{l}\text { See anthropogenic } \\
\text { impacts on environment } \\
\text { (2) }\end{array}$ & & & \\
\hline & & $\begin{array}{l}\text { Be able to identify local } \\
\text { species }\end{array}$ & & & \\
\hline & & $\begin{array}{l}\text { Water quality } \\
\text { investigation }\end{array}$ & & & \\
\hline & & $\begin{array}{l}\text { See equipment used to } \\
\text { monitor climate and } \\
\text { global warming }\end{array}$ & & & \\
\hline & & $\begin{array}{l}\text { Gain an attention to } \\
\text { detail in } \\
\text { environmental } \\
\text { observations }\end{array}$ & & & \\
\hline
\end{tabular}

Each response is listed and if duplicate responses were indicated by more than one student, this is indicated in parentheses (\# of students providing such a response). 
Table 2. Categorization of comments for "ways to improve fieldtrip"

\begin{tabular}{|c|c|c|c|c|}
\hline Content & Explanations/delivery & Preparation & Report/handout & Logistics \\
\hline $\begin{array}{l}\text { Reference points in } \\
\text { the itinerary, in } \\
\text { order to better } \\
\text { follow commentary } \\
\text { (4) }\end{array}$ & $\begin{array}{l}\text { Difficult to hear } \\
\text { instructor (5) }\end{array}$ & $\begin{array}{l}\text { Give worksheet } \\
\text { out prior to trip }\end{array}$ & $\begin{array}{l}\text { More time to } \\
\text { complete the } \\
\text { worksheet/do not hand } \\
\text { it in on the same day } \\
\text { (3) }\end{array}$ & $\begin{array}{l}\text { Better } \\
\text { weather/postpone } \\
\text { trip if it } \\
\text { rains/attention to } \\
\text { tides (11) }\end{array}$ \\
\hline $\begin{array}{l}\text { More emphasis on } \\
\text { site and how it } \\
\text { relates to climate } \\
\text { change, less on } \\
\text { rocks (3) }\end{array}$ & $\begin{array}{l}\text { Shorter explanations } \\
\text { (2) }\end{array}$ & $\begin{array}{l}\text { Need more basic } \\
\text { knowledge on } \\
\text { what we'll } \\
\text { observe } \\
\text { beforehand (7) }\end{array}$ & $\begin{array}{l}\text { Questions of report } \\
\text { are poorly set }\end{array}$ & $\begin{array}{l}\text { Too crowded/too } \\
\text { many students (10) }\end{array}$ \\
\hline $\begin{array}{l}\text { Look at a greater } \\
\text { variety of } \\
\text { landscapes }\end{array}$ & $\begin{array}{l}\text { Knowing what to look } \\
\text { at, and in what order }\end{array}$ & $\begin{array}{l}\text { Lecture about } \\
\text { rocks or geology } \\
\text { vocabulary before } \\
\text { trip (4) }\end{array}$ & & Later start (4) \\
\hline $\begin{array}{l}\text { Carry out some } \\
\text { experiments }\end{array}$ & Less jargon & & & $\begin{array}{l}\text { Shorter trip } \\
\text { overall/move from } \\
\text { stop to stop more } \\
\text { quickly (4) }\end{array}$ \\
\hline \multirow[t]{6}{*}{$\begin{array}{l}\text { Provide a reading } \\
\text { file on Lai Chi } \\
\text { Chong after the trip }\end{array}$} & & & & Safety concerns (3) \\
\hline & & & & $\begin{array}{l}\text { Need a place for } \\
\text { lunch/restaurant (2) }\end{array}$ \\
\hline & & & & $\begin{array}{l}\text { Make the trip } \\
\text { optional }\end{array}$ \\
\hline & & & & $\begin{array}{l}\text { Date of trip - pick a } \\
\text { time during reading } \\
\text { week }\end{array}$ \\
\hline & & & & $\begin{array}{l}\text { Shorter boat trip } \\
\text { (sea sickness) }\end{array}$ \\
\hline & & & & $\begin{array}{l}\text { Add some } \\
\text { recreation time }\end{array}$ \\
\hline
\end{tabular}

Each response is listed and if duplicate responses were indicated by more than one student, this is indicated in parentheses (\# of students providing such a response). 
Table 3. Categorization of comments for "one thing you will remember"

\begin{tabular}{|l|l|l|l|}
\hline $\begin{array}{l}\text { Pertaining to } \\
\text { geology/rocks }\end{array}$ & Landform/historical & General Learning & Logistics/travel \\
\hline Beauty of rocks (14) & $\begin{array}{l}\text { There was once seismic } \\
\text { activity in Hong Kong (2) }\end{array}$ & $\begin{array}{l}\text { Learning through activities } \\
\text { is better than learning from a } \\
\text { textbook }\end{array}$ & Boat incident (11) \\
\hline $\begin{array}{l}\text { Specifics with rock } \\
\text { composition/formation } \\
\text { (carbon content/zigzag } \\
\text { patterns/color) (9) }\end{array}$ & $\begin{array}{l}\text { Hong Kong was once a } \\
\text { volcanic area }\end{array}$ & $\begin{array}{l}\text { Global climate change can } \\
\text { be investigated via various } \\
\text { sources }\end{array}$ & Bad weather (2) \\
\hline $\begin{array}{l}\text { Rock climbing (7) } \\
\text { Touching/categorizing } \\
\text { rocks with multiple senses } \\
\text { (4) }\end{array}$ & $\begin{array}{l}\text { Unique landforms along the } \\
\text { coast of Lai Chi Chong }\end{array}$ & & Sea and fresh air \\
\hline Difficulty in rock analysis & & & Ferry trip \\
\hline $\begin{array}{l}\text { Realization that different } \\
\text { types of rocks exist }\end{array}$ & & & \\
\hline
\end{tabular}

Each response is listed and if responses were indicated by more than one student, this is indicated in parentheses (\# of students providing such a response).

Table 4. Comparison of fieldtrip expectation and evaluative data

\begin{tabular}{|l|l|}
\hline Our student's expectations - what they wanted to know & $\begin{array}{l}\text { Our student evaluations - what they felt they } \\
\text { learned/experienced }\end{array}$ \\
\hline $\begin{array}{l}\text { To learn how climate affects the environment by seeing a } \\
\text { tangible change or historical progression in the landforms }\end{array}$ & $\begin{array}{l}\text { "Global climate change can be investigated via } \\
\text { various sources" }\end{array}$ \\
\hline $\begin{array}{l}\text { To gain local knowledge of how global climate change pertains } \\
\text { specifically to Hong Kong }\end{array}$ & $\begin{array}{l}\text { "There was once seismic activity in Hong Kong” } \\
\text { "Hong Kong was once a volcanic area" }\end{array}$ \\
\hline $\begin{array}{l}\text { To gain practical knowledge, such as how to analyze rock } \\
\text { formations, and perform some simple experiments and data } \\
\text { collection }\end{array}$ & $\begin{array}{l}\text { "How to observe different characteristics of } \\
\text { "Tocks" (grain size, layering, structures, etc.) } \\
\text { "Touching/categorizing rocks with multiple } \\
\text { senses" }\end{array}$ \\
\hline $\begin{array}{l}\text { Application of lecture knowledge to the field } \\
\text { environment/relate information gained on trip back to lectures }\end{array}$ & $\begin{array}{l}\text { "Learning through activities is better than } \\
\text { learning from a textbook" }\end{array}$ \\
\hline Some emotional impact through closer contact with nature & "Beauty of rocks" \\
\hline Leisure & $\begin{array}{l}\text { "rock climbing” } \\
\text { "sea and fresh air" }\end{array}$ \\
\hline
\end{tabular}


Table 5. Moving forward

\begin{tabular}{|l|l|l|}
\hline Activity & 2011 (completed) & 2012-onward (planned) \\
\hline Pre-trip planning & $\begin{array}{l}\text { Accomplished in lecture time } \\
\text { All students were exposed to the } \\
\text { same material to prepare for the } \\
\text { fieldtrip }\end{array}$ & $\begin{array}{l}\text { Self-directed by students } \\
\text { Division of students into groups to } \\
\text { tackle an environmental issue } \\
\text { specific to Hong Kong, on multiple } \\
\text { fronts } \\
\text { Groups will prepare based on their } \\
\text { assigned tasks }\end{array}$ \\
\hline Trip & $\begin{array}{l}\text { Synchronous, in that all students are } \\
\text { engaged in the fieldwork at the same } \\
\text { time fame } \\
\text { Listen, observe and fill-out } \\
\text { worksheet with climate change and } \\
\text { site-specific questions }\end{array}$ & $\begin{array}{l}\text { Asynchronous, with students playing } \\
\text { multiple roles: } \\
\text { i) data collection } \\
\text { ii) interpretation of results } \\
\text { iii) dissemination of results to }\end{array}$ \\
\hline Post-trip & $\begin{array}{l}\text { Short phase of finishing trip } \\
\text { worksheets questions and evaluating } \\
\text { the trip itself }\end{array}$ & $\begin{array}{l}\text { Have a debriefing and critique } \\
\text { session where the groups } \\
\text { explain/justify their methods } \\
\text { Major emphasis on rationale for } \\
\text { each subgroup's methods }\end{array}$ \\
\hline Relevance of trip & $\begin{array}{l}\text { Linkage of climate to environmental } \\
\text { and geological signs } \\
\text { Hands-on for all students }\end{array}$ & $\begin{array}{l}\text { Specifically address an } \\
\text { environmental issue in Hong Kong - } \\
\text { generate data of interest to the } \\
\text { citizenry and for publication in a } \\
\text { peer-reviewed scientific journal } \\
\text { (ideal aim) }\end{array}$ \\
\hline
\end{tabular}


Q1: This field trip had a significant impact on my learning in the course

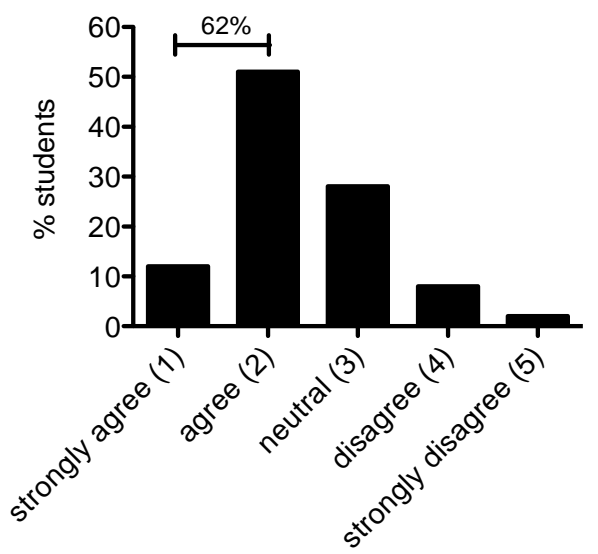

Q3: I learned some skills and knowledge of the subject that I could not have learned in a classroom context

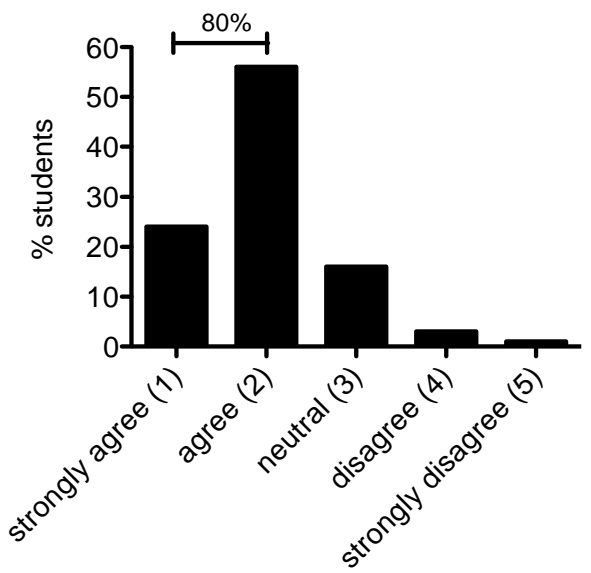

Q5: I am more comfortable with teachers/students in the field trip time than in the classroom

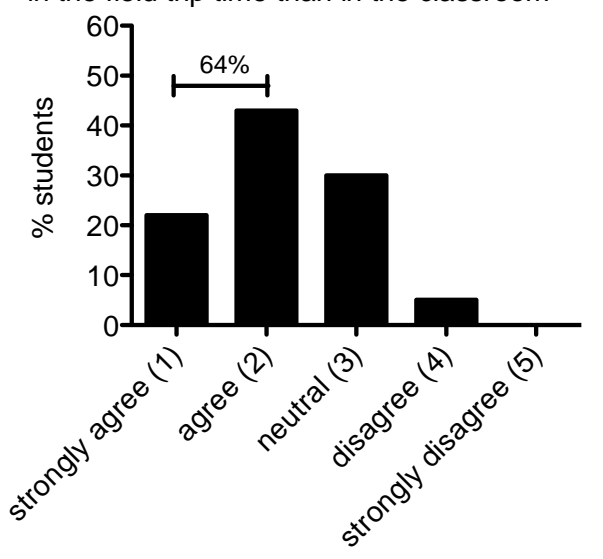

Q2: As a result of the field trip, I understand the subject matter better than before

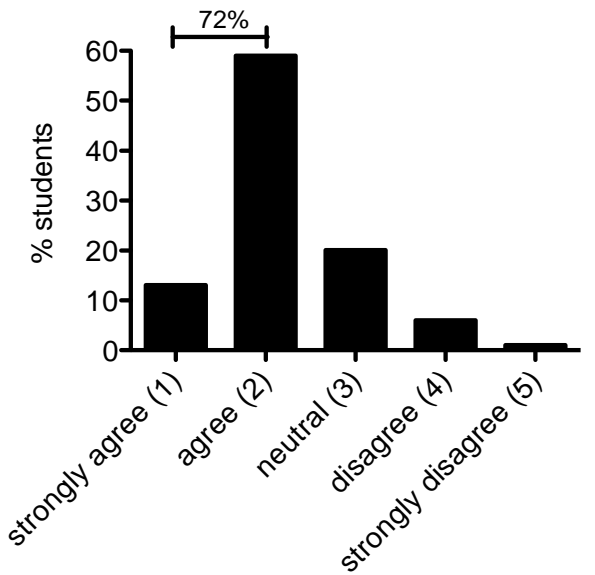

Q4: I have changed to a more positive attitude towards filed trips as learning activities

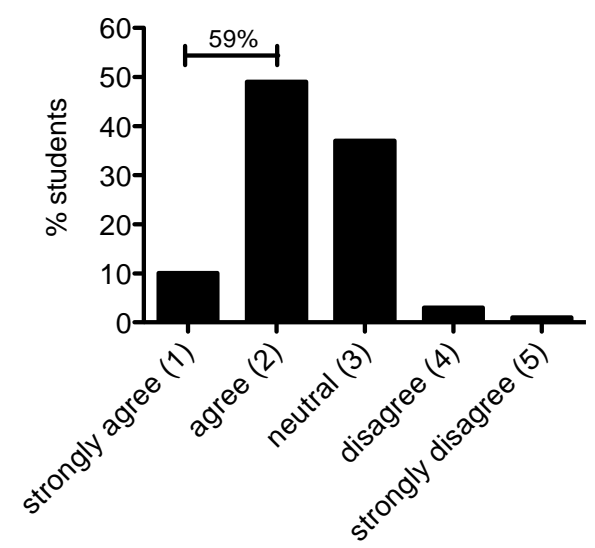

Q6: Overall, I think the field trip has enhanced my learning and interest for the course

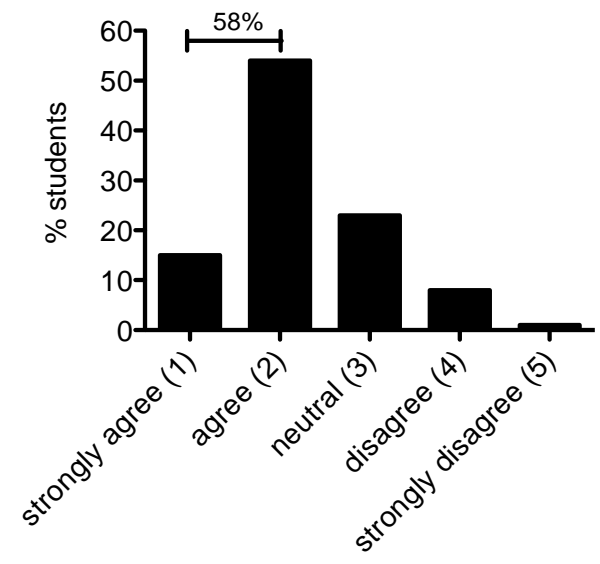

Figure 1. Responses (1-6, Likert scale segment) to the fieldtrip evaluation questionnaire; the percentage of students either agreeing or strongly agreeing for the response is indicated in the top left segment of each graph. 

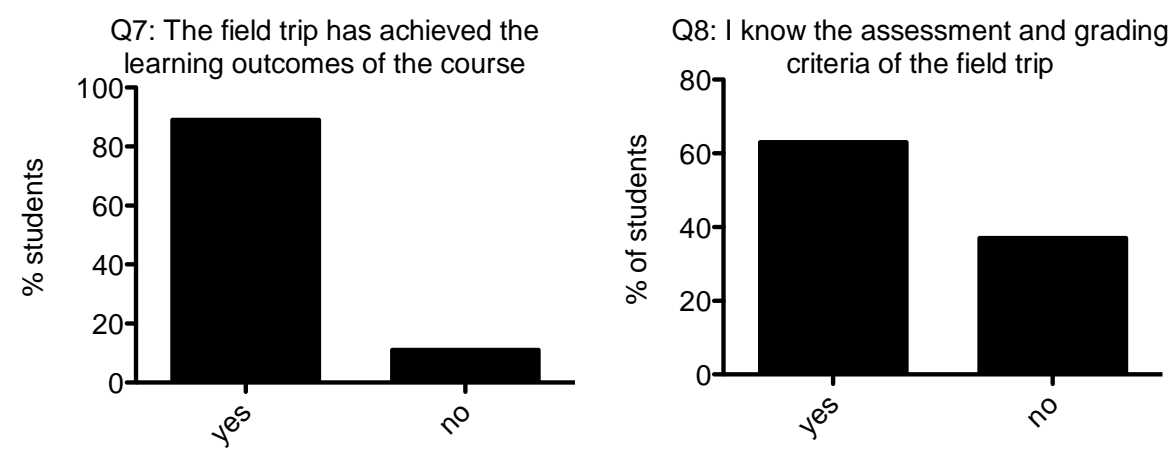

Figure 2. Results from yes/no segment of evaluative questionnaire
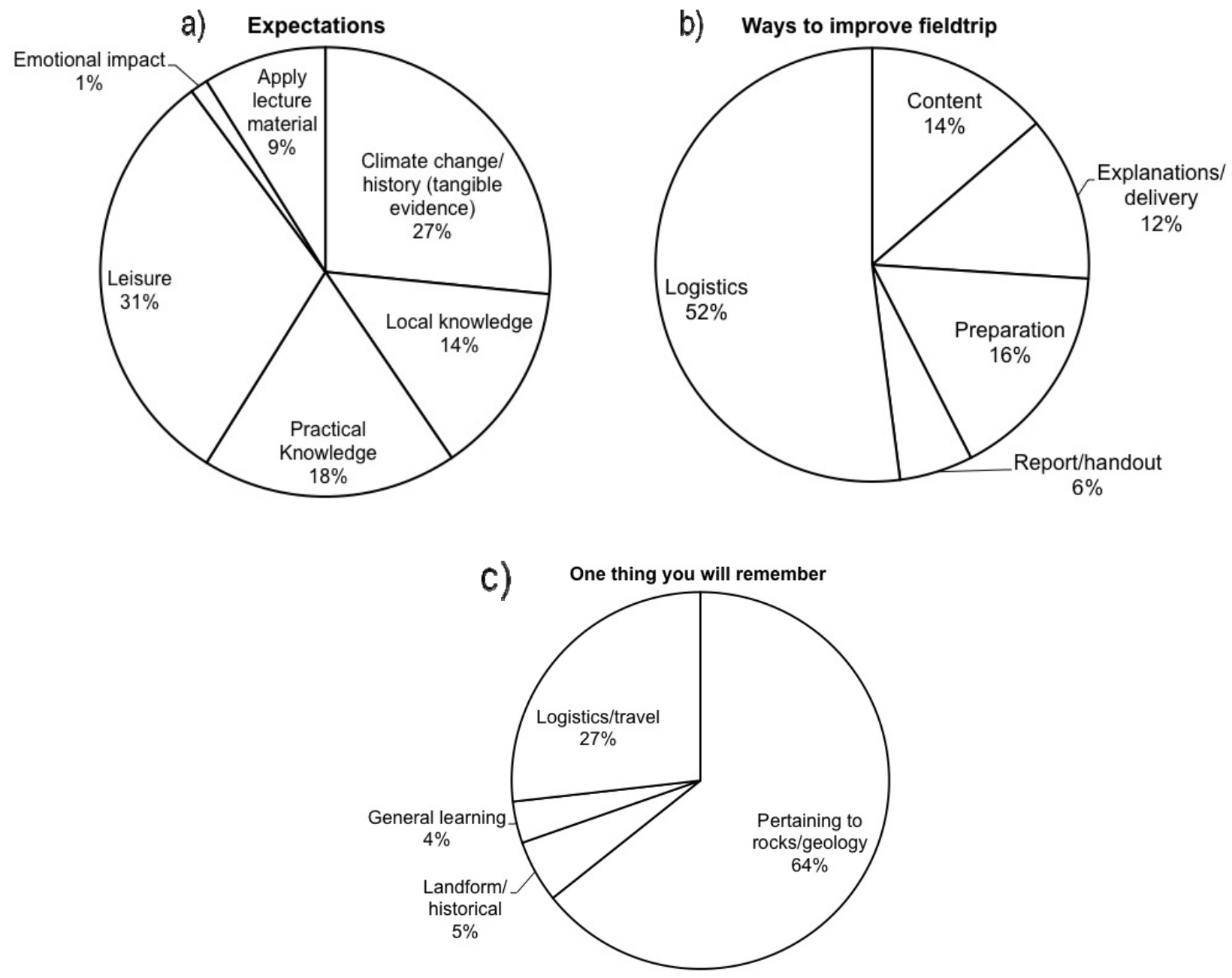

Figure 3. Categorization and percentage of responses from expectation (a) and evaluative (b, c) questionnaires 